\title{
Articulo Original / Original Article \\ Variation in phenolic, antioxidant and vitamin amounts among some medicinal plants and investigation by PCA analysis: Lamiaceae family
}

\author{
[Variación en las cantidades de fenoles, antioxidantes y vitaminas entre algunas plantas medicinales e \\ investigación por análisis PCA: familia Lamiaceae]
}

\author{
Ayşe Usanmaz Bozhüyük ${ }^{1}$, Şaban Kordalı ${ }^{2}$, Adem Güneş ${ }^{3}$, Erman Beyzi ${ }^{4}$, Metin Turan $^{5}$ \& Nilda Ersoy ${ }^{6}$ \\ ${ }^{1}$ Department of Plant Protection, Faculty of Agriculture, Iğdir University, Iğdir, Turkey \\ ${ }^{2}$ Department of Plant Protection, Faculty of Fethiye Agriculture, Muğla Sitki Koçman University, Muğla, Turkey \\ ${ }^{3}$ Department of Soil Science and Plant Nutrition, Faculty of Agriculture, Erciyes University, Kayseri, Turkey \\ ${ }^{4}$ Department of Field Crops, Faculty of Agriculture, Erciyes University, Kayseri, Turkey \\ ${ }^{5}$ Department of Genetics and Bioengineering, Faculty of Engineering and Architecture, Yeditepe University, Kayisdagi, \\ Istanbul, Turkey \\ ${ }^{6}$ Department of Organic Agriculture, Vocational School of Technical Science, Akdeniz University, Antalya, Turkey
}

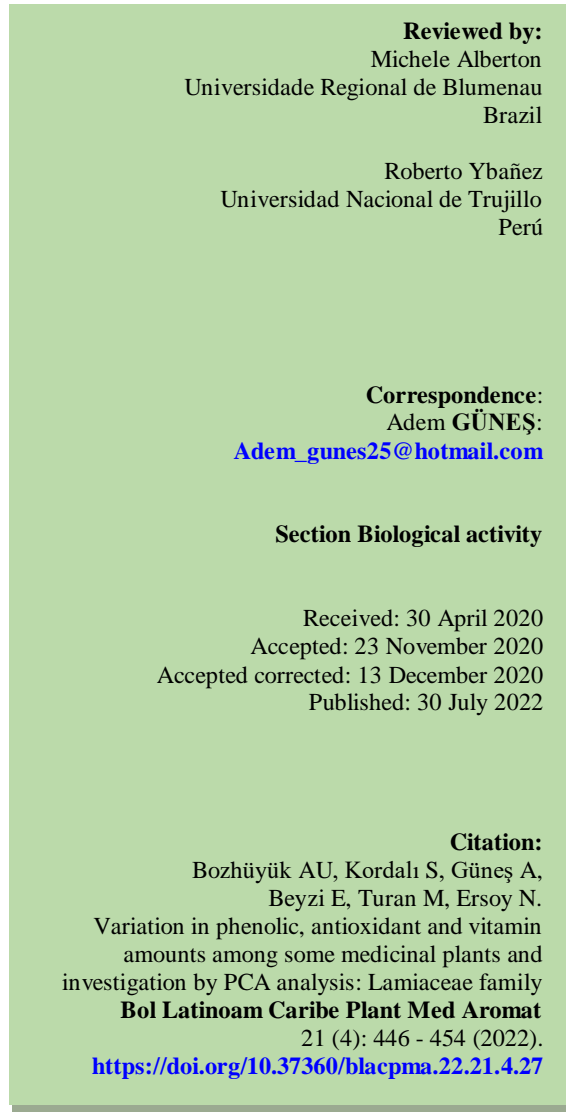

Abstract: Aromatic and medicinal plants are of great importance to determine the contents of the active compounds of plant origin and to evaluate them depending on variety and climate factors in order to determine the phenolic, antioxidant enzyme activity, vitamin contents in species belonging to the Lamiaceae family. Examination of the characteristics of different species, the highest peroxidase (POD) enzyme activity, ascorbate peroxidase (AxPOD), total antioxidant (TA), malondialdehyte (MDA), caffeic acids (CA), vitamin $\mathrm{C}$ contents, and chloric acid (ChA) were obtained in the M. longifolia species. The highest vitamin E and catalase (CAT) were determined in the $S$. hortensis species but the highest total phenolic (TP), superoxide dismutase (SOD) enzyme, hydrogen peroxide $\left(\mathrm{H}_{2} \mathrm{O}_{2}\right)$ and chlorogenic acid (ChgA) were determined in the S. spicigera species. As a result of PCA analysis, it can be said that Mentha longifolia (L.) Hudson and Satureja spicigera species have significant value in terms of biochemical and phenolic content.

Keywords: Antioxidant; Lamiaceae; Medicinal plants; Phenolic contents; Principal component analysis (PCA)

Resumen: Las plantas aromáticas y medicinales son de gran importancia para determinar el contenido de los compuestos activos de origen vegetal y evaluarlos en función de la variedad y factores climáticos con el fin de determinar la actividad enzimática fenólica, antioxidante, contenido vitamínico en especies pertenecientes a la familia Lamiaceae. El examen de las características de diferentes especies, la mayor actividad enzimática de peroxidasa (POD), ascorbato peroxidasa (AxPOD), antioxidante total (TA), malondialdehído (MDA), ácidos cafeicos (CA), contenido de vitamina C y ácido clorhídrico (ChA) se obtuvieron en la especie $M$. longifolia. La mayor cantidad de vitamina E y catalasa (CAT) se determinó en la especie $S$. hortensis, pero la mayor cantidad total de enzima fenólica (TP), superóxido dismutasa (SOD), peróxido de hidrógeno $\left(\mathrm{H}_{2} \mathrm{O}_{2}\right)$ y ácido clorogénico (ChgA) se determinó en la especie $S$. spicigera. Como resultado del análisis de PCA, se puede decir que las especies Mentha longifolia (L.) Hudson y Satureja spicigera tienen un valor significativo en términos de contenido bioquímico y fenólico.

Palabras clave: Antioxidante; Lamiaceae; Plantas medicinales; Contenido fenólico; Análisis de componentes principales (PCA) 


\section{INTRODUCTION}

The demand for medicinal and aromatic plants increases almost daily. These aromatic plants play a very important role in living things in ecosystems as a marker of health conditions due to changes in environmental conditions (Firenzuoli \& Gori, 2007; Jamshidi-Kia et al., 2018). More than 50.000 species of aromatic plants are used in many fields such as cosmetics and pharmaceuticals. Since these plants are generally collected from the wildlife population, they are not homogeneous in content (Huang, 2011; Rafieian-Kopaei, 2012). Medicinal and aromatic plants have different components with their medicinal content and can be used in different fields with their rich content. Different types of seeds, roots, leaves, fruits, flowers, or even the above-ground biomass of these plants, can be used.

The active compounds found as the main agents in the plant provide important insight into the direct or indirect use of such plants (Rasool-Hassan, 2012). Natural antioxidants such as polyphenols and carotenoids found in medicinal and aromatic plants show a wide variety of biological effects as antidisease and endurance enhancers. It is important to investigate the potential amounts of antioxidants contained in these plants and to reveal differences in species to support application in different uses (Xu et al., 2017). In biological systems, reactive nitrogen (RNS), reactive oxygen (ROS) and nitric oxide radicals are a types of (RNS), depending on the stress conditions, can damage DNA and cause degradations of proteins (Peng et al., 2014; Li et al., 2015).

Healthy living conditions require not only the consumption of vegetables and fruits but also the consumption of plants with high active ingredients of medicinal and aromatic plants in order to avail of the high antioxidant content (Jastrzebski et al., 2007). In the literature, antioxidant capacity and phenolic contents of medicinal and aromatic plants were found to be significantly positive and it was stated that phenolic compounds contributed to increasing antioxidant activity (Song et al., 2010). Studies have shown that some medicinal and aromatic plants from some regions have stronger antioxidant content and that phenolic compounds in these plants contribute significantly to antioxidant activity (Schinella et al., 2002; Dragland et al., 2003; Cai et al., 2004).

Principal component analyses (PCA) is a statistical method that is about passing data represented by a large number of variables to basic components that can explain the total variance with a mathematical transformation. This analysis was performed to explain and interpret these multivariate and highly correlated data sets better (Guei et al., 2005).

The antioxidant, and phenolic contents of medicinal and aromatic plants can vary widely depending on the species. Therefore, it is very important to determine that the differences between these species and the active substances according to their purpose of usage. For this purpose, in the present study, antioxidant, phenolic and some vitamin contents of some species belonging to the Lamiaceae family were investigated.

\section{MATERIAL AND METHODS Materials}

Plants used in this study are from regions in eastern Turkey in 2017 were collected. Above-ground parts and flowers were sampled and analyzed as fresh tissue at $-40^{\circ} \mathrm{C}$. These collected plants were described in Atatürk University. Plants used in this study include some species of the Lamiaceae family Lavandula angustifolia Miller., Melissa officinalis L., Nepeta meyeri Benth., Origanum majorana L., Origanum onites L., Origanum syriacum L., Origanum vulgare L., Rosmarinus officinalis L., Salvia officinalis L., Salvia sclarea L., Satureja cuneifolia Ten., Satureja hortensis L. and Satureja spicigera (C. Koch) Boiss. (flowers and leaves); Lycopus europaeus L., Mentha aquatica L. and Mentha longifolia $\mathrm{L}$. (leaves). The leaves and flowers of the plants were separated from each other for analysis. The samples were then weighed and stored at $-20{ }^{\circ} \mathrm{C}$ for some physiological analyses.

\section{Determination of antioxidant enzymes}

To determine the antioxidant enzymes of the Lamiaceae species, plant samples that flowers and leaves, depending on the variety were homogenized with phosphate buffer and frozen. Then these samples were extracted with phosphate buffer containing EDTA+PMSF (fenilmetil sülfonil florit)+PVP (polyvinylpyrolidone). The POD, SOD, CAT, and AxPOD were measured with a spectrophotometer (Sairam \& Srivastava, 2002)

\section{Determination of hydrogen peroxide and lipid peroxidation concentration}

The hydrogen peroxide $\left(\mathrm{H}_{2} \mathrm{O}_{2}\right)$ was measured according to a study of Loreto and Velikova (2001). So, one gram fresh leaf or flower samples were homogenized in tri-chloroacetic acid (TCA) approximately five minutes. Lipid peroxidation was

\section{Boletín Latinoamericano y del Caribe de Plantas Medicinales y Aromáticas / 447}


measured by the content of total 2-thiobarbituric acid reactive substances and then the taken supernatant was recorded at $532 \mathrm{~nm}$ on a spectrophotometer (Cakmak and Horst, 1991; Du et al., 2010).

\section{Determination of total phenolic contents}

One gram fresh leaf or flower samples of the plants were taken for analysis. Hexane: dichloromethane (1:2) was added to the samples and shaken for one hour. After shaking, the mixture was centrifuged. Acetone, water, and acetic acid were added to the resulting precipitate. The supernatant obtained after a series of treatments were analyzed (Katsube et al., 2004; Spiridon et al., 2011).

\section{Determination of total antioxidant content and carotenoid contents}

According to Prieto et al. (1999), the total antioxidant content was analyzed. $0.1 \mathrm{ml}$ of sample solution containing flower or leaves of plants was combined in an Eppendorf tube with $1 \mathrm{ml}$ of reagent solution (0.6 M sulfuric acid, $28 \mathrm{mM}$ sodium phosphate, and 4 $\mathrm{mM}$ ammonium molybdate). The resulting solution was determined by reading on a spectrophotometer at a wavelength of $695 \mathrm{~nm}$. For total carotenoid content, one gram sample was mixed with $30 \mathrm{ml} 30 \%$ acetone and homogenized. Then a mixture of samples was measured using the spectrophotometer (Lichtentaler \& Wellburn, 1985).

\section{Determination of vitamin $E$ and $C$ contents}

For the determination of vitamin $E$ and $C$ of plant, vitamin $\mathrm{E}$ was measured from leaves using the methods reported by Kumar et al. (2013), and vitamin $\mathrm{C}$ was measured using the methods reported by AOAC (1990).

\section{Determination of chlorogenic, chiroic acids, caffeic, and proanthocyanidin contents}

For the determination of chlorogenic, chiroic acids, caffeic, and proanthocyanidin contents of plants, reverse-phase analytical column and a mobile phase were separated. The HPLC conditions were as following: a C18 $(250 \times 4.6 \mathrm{~mm}$ i.d.; $5 \mu \mathrm{m}$ particle size; $100 \AA$ pore size) column; the mobile phase of the mixture of acetonitrile and $0.5 \%$ aqueous phosphoric acid (11.5:88.5 v/v); the flow rate of 1.0 $\mathrm{mL} \min ^{-1}$ and determination wavelength of $327 \mathrm{~nm}$. At the end of the separation process, the extracts were determined by a reading on HPLC (Mocan et al., 2015) and on a spectrophotometer (Hümmer \& Schreier, 2008).

\section{Principal component analysis (PCA)}

Principal component analysis (PCA) was performed with the aid of XLSTAT software (Addinsoft (2019). XLSTAT statistical and data analysis solution. Boston, USA. https://www.xlstat.com

\section{RESULTS AND DISCUSSION \\ Evaluation of antioxidant enzymes of Lamiaceae species}

In this study, CAT, POD and SOD enzyme activities, and AxPOD, MDA, hydrogen peroxidase, TA of some species of the Lamiaceae family were determined. As a result, significant changes were determined between species (Table No. 1). The highest SOD enzyme and $\mathrm{H}_{2} \mathrm{O}_{2}$ were measured from Satureja spicigera (74.38 EU g leaf ${ }^{-1}, 9.21 \mu \mathrm{mol} \mathrm{g}{ }^{-1}$ fw, respectively) but the highest CAT enzyme was obtained from Satureja hortensis (from Mentha longifolia (L.) Hudson (1511.00 EU g leaf ${ }^{-1}$ ). The highest POD enzyme activity, AxPOD, MDA, and TA were obtained from Mentha longifolia (L.) Hudson (357.65 EU g leaf ${ }^{-1}$, 34.57 EU g leaf ${ }^{-1}$ $102.89 \mathrm{nmol} \mathrm{g}^{-1}, 1173.67 \mu \mathrm{mol}$ TE per $\mathrm{g}^{-1} \mathrm{fw}$, respectively),

When the lowest antioxidant enzyme activity was examined, the lowest CAT enzyme activity and MDA were determined from $N$. meyeri, the lowest SOD enzyme activity, and $\mathrm{H}_{2} \mathrm{O}_{2}$ were determined from M. longifolia. But the lowest POD and AxPOD were determined from $S$. spicigera.

The presence of sufficient compounds such as vitamin $\mathrm{C}$ and vitamin $\mathrm{A}$ in the plant cell and antioxidants increase plant resistance under stress conditions, while insufficient levels of antioxidants can cause oxidative stress (Valko et al., 2007). Most medicinal-aromatic plants contain antioxidants. Some non-nutritive and anti-nutritive complexes are included in such plants. Therefore, the nutritional status and nutritional properties of the plants examined should be known (Rehman \& Adnan, 2018).

ROS detoxification agents in cells include antioxidant enzymes such as catalase, superoxide dismutase, and ascorbate peroxidase. Enzymatic antioxidants serve as defense agents in plants that are resistant to oxidative damage (Verma and Dubey, 2003; Lee et al., 2007). Superoxide dismutase protects plants from the toxicity of reactive oxygen species produced for energy production. As a result of this effect, more toxic superoxide radical is converted to the less toxic hydrogen peroxide (Vangronsveld \& Clijsters, 1994). The CAT enzyme

\section{Boletín Latinoamericano y del Caribe de Plantas Medicinales y Aromáticas / 448}


is an enzyme that catalyzes the decomposition of $\mathrm{H}_{2} \mathrm{O}_{2}$ (Scandalios, 1987).

Similarly, in the present study, the highest total antioxidant content and the lowest hydrogen peroxide value were obtained in the $M$. longifolia plant, which had the highest POD, AxPOD and MDA values.

Table No. 1

Biochemical contents of some species of the Lamiaceae family

\begin{tabular}{|c|c|c|c|c|c|c|c|}
\hline \multirow[t]{2}{*}{ Species } & POD & CAT & AxPOD & SOD & MDA & TA & $\mathrm{H}_{2} \mathrm{O}_{2}$ \\
\hline & \multicolumn{4}{|c|}{$\begin{array}{l}\text { EU g } \\
\text { leaf }^{-1}\end{array}$} & $\begin{array}{c}\mathrm{nmol}^{-1} \\
\mathrm{~g}^{-1} \\
\mathrm{fW}\end{array}$ & $\begin{array}{c}\mu \mathrm{mol} \\
\text { TE per } \\
\mathrm{g}^{-1} \mathrm{fw}\end{array}$ & $\begin{array}{c}\mu \mathrm{mol} \\
\mathrm{g}^{-1} \\
\mathrm{fw}\end{array}$ \\
\hline Lavandula angustifolia Miller. & 238.56 & 1288.91 & 24.77 & 36.27 & 85.20 & 890.06 & 2.90 \\
\hline Lycopus europaeus L. & 238.02 & 1019.57 & 28.22 & 37.57 & 64.07 & 1023.05 & 3.13 \\
\hline Melissa officinalis L. subsp. officinalis & 171.33 & 1046.11 & 20.85 & 41.05 & 64.42 & 777.42 & 3.66 \\
\hline Mentha aquatica $\mathrm{L}$. & 117.38 & 973.33 & 22.47 & 59.31 & 60.08 & 717.87 & 3.37 \\
\hline Mentha longifolia (L.) Hudson & 357.65 & 1511.00 & 34.57 & 32.68 & 102.89 & 1173.67 & 2.09 \\
\hline Nepeta meyeri & 93.40 & 613.85 & 19.30 & 72.41 & 30.11 & 796.38 & 8.86 \\
\hline Origanum majorana & 122.77 & 671.62 & 19.99 & 48.12 & 36.63 & 780.48 & 4.99 \\
\hline Origanum onites & 112.28 & 727.79 & 18.91 & $\mathbf{5 0 . 3 9}$ & 38.68 & 730.90 & 4.72 \\
\hline Origanum syriacum & 84.30 & 789.98 & 18.91 & 67.12 & 45.43 & 627.01 & 4.25 \\
\hline Origanum vulgare & 146.73 & 1216.67 & 28.08 & 74.14 & 75.10 & 897.33 & 4.21 \\
\hline Rosmarium officinalis L. & 156.33 & 896.71 & 22.47 & 44.53 & 51.16 & 836.81 & 3.74 \\
\hline Salvia officinalis L. & 163.44 & 1199.24 & 26.69 & 52.41 & 79.46 & 821.88 & 2.67 \\
\hline Salvia sclarea & 144.86 & 745.50 & 21.79 & 45.23 & 42.13 & 835.11 & 4.44 \\
\hline Satureja cuneifolia & 104.28 & 764.91 & 16.10 & 49.42 & 42.36 & 634.60 & 5.19 \\
\hline Satureja hortensis & 204.30 & 1499.05 & 33.36 & 65.51 & 99.32 & 1027.35 & 3.33 \\
\hline Satureja spicigera & 79.33 & 699.12 & 15.54 & 74.38 & 34.82 & 647.53 & 9.21 \\
\hline
\end{tabular}

POD: Peroxidase, CAT: catalase, AxPOD: ascorbate peroxidase, SOD: superoksid dismutase, MDA: malondialdehyte, TA: total antioxidant, H2O2: hydrogen peroxide

\section{Determination of phenolic and vitamin contents of the Lamiaceae family}

The phenolic content of these plants may vary significantly depending on plant species and climatic factors. In some phytochemical studies, the phenolic contents of medicinal-aromatic plants were obtained. These values were determined to be 0.19 to 101.33 mg of GAE g-1 DW (Li et al., 2013), 0.38 to 75.71 $\mathrm{mg}$ of GAE g ${ }^{-1} \mathrm{DW}$ (Gan et al., 2010a) and 0.12 to $59.43 \mathrm{mg}$ of GAE $\mathrm{g}^{-1} \mathrm{DW}$ and showed significant differences between species (Gan et al., 2010a).

Phenolic compounds in plants are plant metabolites characterized by several phenol groups. Some of these phenolic compounds exhibit reactive properties in neutralizing and chelating free radicals. Phenolic compounds in plants are important sources of antioxidants for different uses, such as in foods. Naturally grown and used sources contain various phenolic compounds with variable antioxidant activity. Because of these contents, the activity of phenolic compounds may be higher than their individual uses. Song et al. (2010), found that the phenolic content of the plants ranged between 0.12-
59.43 mg GAE g-1. Duran et al. (2015) determined that the total phenolics varied significantly and ranged between 0.411-3.337 mg GAE $100 \mathrm{ml}^{-1}$. As a result of these differences in phenolic compounds in plants, it is stated that plants contain phenolic with multiple biological properties and these contents may vary depending on their antioxidant activities (Shui and Leong, 2002; Petti and Scully, 2009).

Vitamins are regarded as important nutrients in the foods used and fulfill specific functions necessary for health. Vitamins are also active in carbohydrate, fat and protein metabolism, and the regeneration of new cells. Especially vitamin C tissues play a protective role against oxidative stress (Whitney \& Rolfe, 2002). However, although there are few studies on this subject, there may be significant differences in vitamin contents depending on the species in general. Plants with high phenolic content are a source of antioxidants. Considering these results, it is important to quantify the total phenolic and phenolic compounds such as chlorogenic, caffeic and chloric acid in plant extracts in order to reveal the beneficial effects of some 
medicinal plants (Gorinstein et al., 2004). In other studies in which the content of phenolic substances was determined, the phenolic contents ranged between 0.42-30.27 $\mu \mathrm{g}$ GAE $\mathrm{mg}^{-1}$ (Gulati et al., 2012), 20.90 to $83.25 \mathrm{mg} \mathrm{GAE} \mathrm{g}^{-1}$ (Zengin et al., 2015).

When these results evaluated, significant differences were observed in the phenolic contents of such as Hedysarum varium, Onobrychis hypargyrea, and Vicia truncatula. In the present research, the determined total phenolic content ranged between 3.90-18.40 mg GA per $\mathrm{g}^{-1} \mathrm{FW}$; total carotenoid ranged between 7.34- $28.24 \mathrm{~g}$ vit A eq $100^{-1}$.

According to the results of the phenolic analysis of some plant species belonging to the Lamiaceae family, significant differences were found between species (Table No. 2). Although the maximum total phenolic and chlorogenic acid were obtained from the Satureja spicigera species, caffeic acids, and chloric acid were obtained from the Mentha longifolia (L.) Hudson species. The highest total carotenoid and proanthocyanidin amount was obtained from the Nepeta meyeri, and Satureja hortensis species, respectively. Vitamin $\mathrm{C}$ and vitamin $\mathrm{E}$ contents of plants were obtained from the highest, Mentha longifolia (L.) Hudson species and Satureja hortensis species, respectively (Figure No. 1).

Table No. 2

Chemical contents of some species of the Lamiaceae family

\begin{tabular}{|c|c|c|c|c|c|c|}
\hline Species & $\begin{array}{c}\text { Total } \\
\text { carotenoid }\end{array}$ & $\begin{array}{c}\text { Total } \\
\text { phenolic }\end{array}$ & $\begin{array}{c}\text { Chlorogenic } \\
\text { acid }\end{array}$ & $\begin{array}{c}\text { Caffeic } \\
\text { acid }\end{array}$ & $\begin{array}{c}\text { Chloric } \\
\text { acid }\end{array}$ & Proantocyanidin \\
\hline & $\begin{array}{c}\text { g vit A eq } \\
100^{-1}\end{array}$ & $\begin{array}{c}\text { mg GA } \\
\text { per g } \\
{ }^{1} \mathrm{FW}\end{array}$ & \multicolumn{3}{|c|}{$m g g^{-1} f w$} & $\%$ \\
\hline Lavandula angustifolia Miller. & 9.57 & 6.34 & 5.91 & 1.03 & 91.73 & 47.76 \\
\hline Lycopus europaeus L. & 11.68 & 3.92 & 5.06 & 1.03 & 70.81 & 52.40 \\
\hline Melissa officinalis L. subsp. officinalis & 11.55 & 7.82 & 7.29 & 0.73 & 73.13 & 37.41 \\
\hline Mentha aquatica $\mathrm{L}$. & 11.59 & 5.33 & 4.93 & 0.58 & 40.38 & 44.47 \\
\hline Mentha longifolia (L.) Hudson & 7.34 & 3.90 & 5.19 & 1.92 & 126.06 & 50.40 \\
\hline Nepeta meyeri & 28.24 & 10.26 & 13.23 & 0.38 & 40.04 & 27.84 \\
\hline Origanum majorana & 17.03 & 5.98 & 7.71 & 0.51 & 45.00 & 32.14 \\
\hline Origanum onites & 14.20 & 8.14 & 10.85 & 0.57 & 57.02 & 21.42 \\
\hline Origanum syriacum & 14.00 & 6.59 & 6.08 & 0.41 & 32.19 & 34.83 \\
\hline Origanum vulgare & 14.49 & 6.67 & 6.16 & 0.72 & 50.48 & 55.59 \\
\hline Rosmarium officinalis L. & 11.76 & 6.60 & 8.79 & 0.81 & 71.53 & 27.36 \\
\hline Salvia officinalis L. & 9.60 & 4.32 & 3.99 & 0.82 & 50.66 & 56.78 \\
\hline Salvia sclarea & 15.49 & 5.38 & 6.94 & 0.61 & 50.40 & 36.31 \\
\hline Satureja cuneifolia & 15.33 & 10.73 & 10.00 & 0.43 & 52.05 & 25.92 \\
\hline Satureja hortensis & 12.00 & 5.40 & 4.99 & 1.02 & 63.32 & 70.98 \\
\hline Satureja spicigera & 25.43 & 18.40 & 17.15 & 0.32 & 46.31 & 22.46 \\
\hline
\end{tabular}

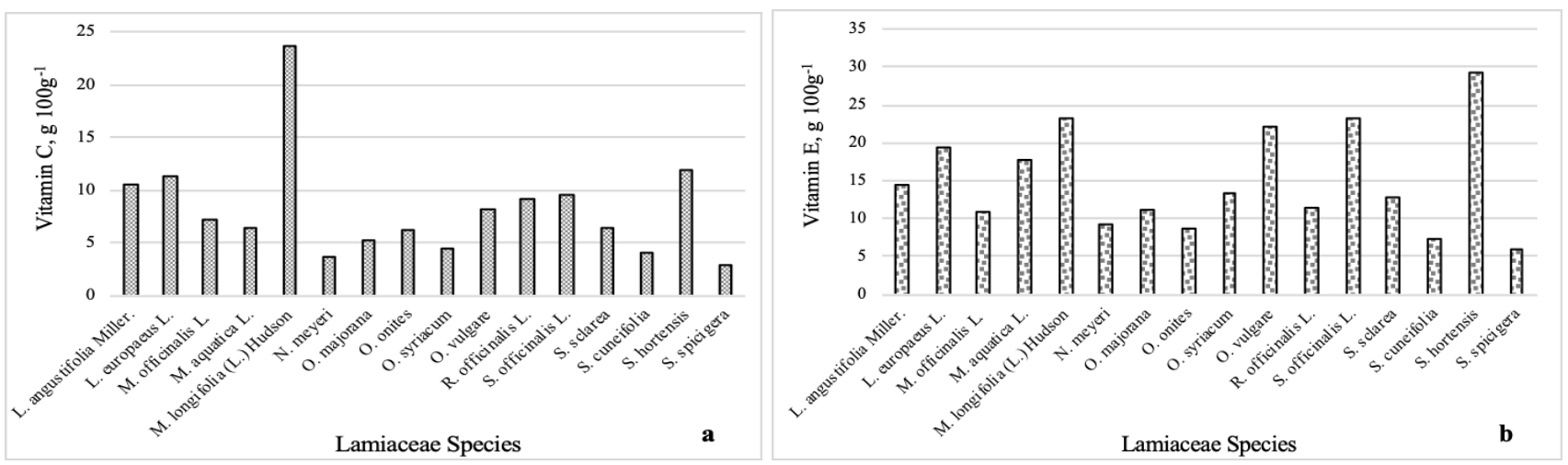

Figure No. 1

Vitamin C (a) and vitamin E (b) contents of Lamiaceae species 


\section{PCA analysis}

As a result of the PCA analysis, PC1 and PC2 explained $89.68 \%$ of the total variance for the biochemical content graph and $87.29 \%$ for the phenolic contents graph. PC1 explained $74.87 \%$ and $69.52 \%$ of the total variance alone in biochemical and phenolic contents, respectively (Figure No. 2). PC1 was found to be related to POD, CAT, AxPOD,
MDA, TA and $\mathrm{H}_{2} \mathrm{O}_{2}$ in biochemical contents and was found to be related to total carotenoid, total phenolic, chlorogenic acid, caffeic acid, proantocyanidin, vitamin $\mathrm{C}$ and vitamin $\mathrm{E}$ in phenolic contents. PC2 was found to be related to SOD in biochemical contents and was found to be related to chloric acid in phenolic contents (Table No. 3).
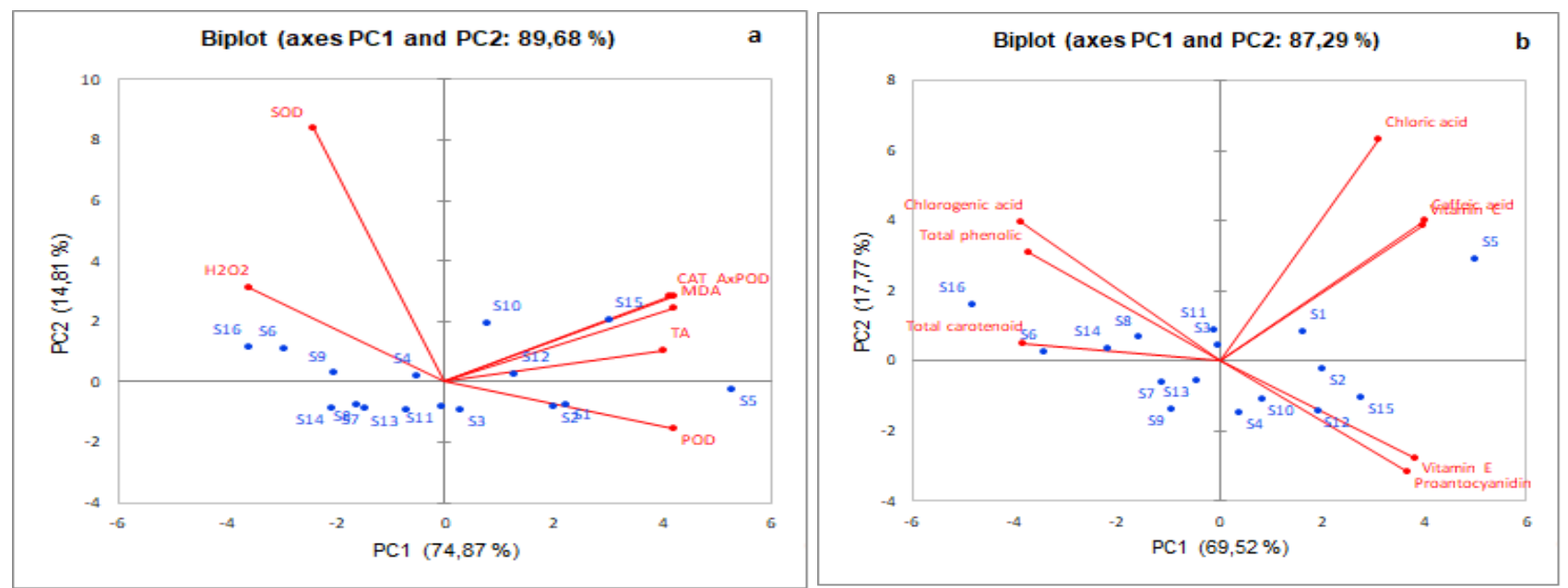

Figure $\mathrm{N}^{\circ} 2$

PCA graphs of the some Lamiaceae species for biochemical contents (a) and phenolic contents (b) S1: Lavandula angustifolia Miller., S2: Lycopus europaeus L., S3: Melissa officinalis L. subsp. Officinalis, S4: Mentha aquatica L., S5: Mentha longifolia (L.) Hudson, S6: Nepeta meyeri, S7: Origanum majorana, S8: Origanum onites, S9: Origanum syriacum, S10: Origanum vulgare, S11: Rosmarium officinalis L., S12: Salvia officinalis L., S13: Salvia sclarea, S14: Satureja cuneifolia, S15: Satureja hortensis, S16: Satureja spicigera

When PCA graph of the species was examined (Figure No. 2a), Satureja spicigera (S16 in graph) was found to be prominent in terms of $\mathrm{H} 2 \mathrm{O} 2$ and SOD, and Mentha longifolia (L.) Hudson (S5 in graph) was found to be prominent in terms of POD. When PCA graph of the species was examined (Figure No. 2b), Satureja spicigera (S16 in graph) was found to be prominent in terms of chlorogenic acid and total phenolic, Mentha longifolia (L.) Hudson (S5 in graph) was found to be prominent in terms of caffeic acid, chloric acid and vitamin $\mathrm{C}$. Therefore, it can be said that these two species (S16 and S5) have significant value in terms of biochemical and phenolic content.

According to the results of antioxidant, phenolic and vitamin analysis of some plant species belonging to the Lamiaceae family, significant content differences were determined depending on the species. In the results of the present study, M. longifolia, S. hortensis and S. spicigera plants were found to be rich in antioxidant enzyme activity, total phenolic content, and vitamins. However, it was determined that the biochemical contents of these plants may vary according to climatic soil and growing conditions and that their contents should be determined before use. It has been attempted to explain the information in a multivariate numerical data set with fewer variables with minimum information loss. PCA analysis was performed to explain and interpret these multivariate and highly correlated data sets better (Guei et al., 2005). As a result of PCA analysis, it can be said that Mentha longifolia (L.) Hudson and Satureja spicigera species have significant value in terms of biochemical and phenolic content. 
Table No. 3

Factor loadings of PCA analysis

\begin{tabular}{lcc}
\hline & PC1 & PC2 \\
\hline Biochemical contents & $\mathbf{0 . 9 4 2}$ & -0.154 \\
POD & $\mathbf{0 . 9 2 6}$ & 0.280 \\
$\mathrm{CAT}$ & $\mathbf{0 . 9 3 7}$ & 0.282 \\
$\mathrm{AxPOD}$ & -0.541 & $\mathbf{0 . 8 3 0}$ \\
$\mathrm{SOD}$ & $\mathbf{0 . 9 3 8}$ & 0.242 \\
$\mathrm{MDA}$ & $\mathbf{0 . 8 9 6}$ & 0.104 \\
$\mathrm{TA}$ & $\mathbf{- 0 . 8 0 2}$ & 0.310 \\
$\mathrm{H}_{2} \mathrm{O}_{2}$ & & \\
\hline Phenolic contents & $\mathbf{0 . 8 5 0}$ & 0.056 \\
Total carotenoid & $\mathbf{- 0 . 8 2 2}$ & 0.346 \\
Total phenolic & $\mathbf{- 0 . 8 5 9}$ & 0.441 \\
Chlorogenic acid & $\mathbf{0 . 8 8 8}$ & 0.445 \\
Caffeic acid & 0.686 & $\mathbf{0 . 7 0 8}$ \\
Chloric acid & $\mathbf{0 . 8 1 3}$ & -0.353 \\
Proantocyanidin & $\mathbf{0 . 8 8 4}$ & 0.429 \\
Vitamin C & $\mathbf{0 . 8 5 1}$ & -0.309 \\
Vitamin E &
\end{tabular}

POD: Peroxidase, CAT: catalase, AxPOD: ascorbate peroxidase, SOD: superoksid dismutase, MDA: malondialdehyte, TA: total antioxidant, $\mathrm{H}_{2} \mathrm{O}_{2}$ : hydrogen peroxide

\section{REFERENCES}

AOAC. 1990. Official methods of Analysis of the Association of Official Analytical Chemists. Association of Official Analytical Chemists, Arlington, VA, USA.

Cai YZ, Luo Q, Sun M, Corke H. 2004. Antioxidant activity and phenolic compounds of 112 traditional Chinese medicinal plants associated with anticancer. Life Science 74: 2157 - 2184.

https://doi.org/10.1016/j.lfs.2003.09.047

Cakmak I, Horst J. 1991. Effect of aluminium on lipid peroxidation, superoxide dismutase, catalase, and peroxidase activities in root tips of soybean (Glycine max). Physiologia Plantarum 83: 463 - 468.

Dragland S, Senoo H, Wake K, Holte K, Blomhoff R. 2003. Several culinary and medicinal herbs are important sources of dietary antioxidants. J Nutr 133: 1286 - 1290. https://doi.org/10.1093/jn/133.5.1286

Du B, Nian H, Zhang Z, Yang C. 2010. Effects of aluminum on superoxide dismutase and peroxidase activities, and lipid peroxidation in the roots and calluses of soybeans differing in aluminum tolerance. Acta Physiologia Plantarum 32: 883 - 890. https://doi.org/10.1007/s11738-010-0476-z

Duran A, Uslu N, Doğan B, Özcan MM, Çelik M. 2015. Antioxidant activity and phenolic contents of 30 selected medicinal plants. J Agroaliment Proc Technol 21: 136 - 141.

Firenzuoli F, Gori L. 2007. Herbal medicine today: clinical and research issues. Evid Based Complement Alt Med 4: $37-40$.

Gan RY, Kuang L, Xu XR, Zhang Y, Xia QE, Song FL, Li HB. 2010b. Screening of natural antioxidants from traditional Chinese medicinal plants associated with treatment of rheumatic disease. Molecules 15: 5988 5997. https://doi.org/10.3390/molecules15095988

Gan RY, Xu XR, Song FL, Lei K, Li HB. 2010a. Antioxidant activity and total phenolic content of medicinal plants associated with prevention and treatment of cardiovascular and cerebrovascular diseases. J Med Plant Res 4: 2438 - 2444.

Gorinstein S, Zachwieja Z, Katrich E, Pawelzik E, Haruenkit R, Trakhtenberg S, Martin-Belloso O. 2004. 
Comparison of the contents of the main antioxidant compounds and the antioxidant activity of white grapefruit and his new hybrid. Lebensm Wiss Technol 37: 337 - 343.

https://doi.org/10.1016/j.lwt.2003.10.005

Guei RG, Sanni KA, Fawole AFJ. 2005. Genetic diversity of rice (O. sativa L.). Agron Afr 5: 17 - 28.

Gulati V, Harding IH, Palombo EA. 2012. Enzyme inhibitory and antioxidant activities of traditional medicinal plants: Potential application in the management of hyperglycemia. BMC Complement Alt Med 12: 77 86. https://doi.org/10.1186/1472-6882-12-77

Huang H. 2011. Plant diversity and conservation in China: planning a strategic bioresource for a sustainable future.

Bot J Linn Soc 166: 282 - 300. https://doi.org/10.1111/j.1095-8339.2011.01157.x

Hümmer W, Schreier P. 2008. Analysis of proanthocyanidins. Mol Nutr Food Res 52: 1381 - 1398. https://doi.org/10.1002/mnfr.200700463

Jamshidi-Kia F, Lorigooini Z, Amini-Khoei H. 2018. Medicinal plants: Past history and future perspective, J Herbmed Pharmacol 7: 1 - 7. https://doi.org/10.15171/jhp.2018.01

Jastrzebski Z, Medina OJ, Moreno LM, Gorinstein S. 2007. In vitro studies of polyphenol compounds, total antioxidant capacity and other dietary indices in a mixture of plants (Prolipid). Int J Food Sci Nutr 58: 531 - 541. https://doi.org/10.1080/09637480701335941

Katsube T, Tabata H, Ohta Y, Yamasaki Y, Anuurad E, Shiwaku K, Yamane Y. 2004. Screening for antioxidant activity in edible plant products: comparison of lowdensity lipoprotein oxidation assay, DPPH radical scavenging assay, and Folin-Ciocalteu assay. J Agric Food Chem 52: 2391 - 2396.

https://doi.org/10.1021/jf035372g

Kumar SS, Samydurai P, Ramakrishnan R, Nagarajan N. 2013. Polyphenols, vitamin-E estimation and in vitro antioxidant activity of Adiantum capillus-veneris. Int J Innov Pharmaceut Sci 4: 258 - 262.

Lee SH, Ahsan N, Lee KW, Kim DH, Lee DG, Kwak SS. 2007. Simultaneous overexpression of both CuZn superoxide dismutase and ascorbate peroxidase in transgenic tall fescue plants confers increased tolerance to a wide range of abiotic stresses. J Plant Physiol 164: 1626 - 1638.

https://doi.org/10.1016/j.jplph.2007.01.003

Li S, Tan HY, Wang N, Zhang ZJ, Lao L, Wong CW, Feng Y. 2015. The role of oxidative stress and antioxidants in liver diseases. Int J Mol Sci 16: 26087 - 26124. https://doi.org/10.3390/ijms161125942

Lichtenthaler HK, Wellburn AR. 1985. Determination of total carotenoids and chlorophylls A and B of leaf in different solvents. Biol Soc Trans 11: 591 - 592. https://doi.org/10.1042/bst0110591

Loreto F, Velikova V. 2001. Isoprene produced by leaves protects the photosynthetic apparatus against ozone damage, quenches ozone products, and reduces lipid peroxidation of cellular membranes. Plant Physiol 127: 1781 - 1787. https://doi.org/10.1104/pp.010497

Mocan A, Vlase L, Arsene LA, Vodnar D, Bischin C, Dumitrescu RS, Crisan G. 2015. HPLC/MS analysis of caffeic and chlorogenic acids from three romanian veronica species and their antioxidant and antimicrobial properties. Farmacia 63: 890 - 896.

Peng C, Wang X, Chen J, Jiao R, Wang L, Li YM, Zuo Y, Liu Y, Lei L, Ma KY, Huang Y, Chen ZY. 2014. Biology of ageing and role of dietary antioxidants. BioMed Res Int 2014: 831841. https://doi.org/10.1155/2014/831841

Petti S, Scully C. 2009. Polyphenols, oral health and disease: a review. J Dentist 37: 413 - 423.

Prieto P, Pineda M, Aguilar M. 1999. Spectrophotometric quantitation of antioxidant capacity through the formation of a phosphor molybdenum complex: specific application to the determination of vitamin $\mathrm{E}$. Anal Biochem 269: 337 - 341. https://doi.org/10.1006/abio.1999.4019

Rafieian-Kopaei M. 2012. Medicinal plants and the human needs. J Herbmed Med Pharmacol 1: 1 - 2.

Rasool-Hassan BA. 2012. Medicinal plants (importance and uses). Pharmaceut Anal Acta 3: 139.

Rehman A, Adnan M. 2018. Nutritional potential of Pakistani medicinal plants and their contribution to human health in times of climate change and food insecurity. Pak J Bot 50: 287 - 300.

Sairam RK, Srivastava GC. 2002. Changes in antioxidant activity in sub-cellular fractions of tolerant and susceptible wheat genotypes in response to long term salt stress. Plant Sci 162: 897 - 904.

https://doi.org/10.1016/s0168-9452(02)00037-7

Scandalios JG.1987. The antioxidant enzyme genes CAT and SOD of maize: regulation, functional significance and molecular biology. Isozymes Curr Topics Biol Med Res 14: 19 - 44.

Boletín Latinoamericano y del Caribe de Plantas Medicinales y Aromáticas / 453 
Schinella GR, Tournier HA, Prieto JM, Mordujovich de Buschiazzo P, Rios JL. 2002. Antioxidant activity of antiinflammatory plant extracts. Life Sci 70: 1023 - 1033. https://doi.org/10.1016/s0024-3205(01)01482-5

Shui G, Leong LP. 2002. Separation and determination of organic acids and phenolic compounds in fruit juices and drinks by high-performance liquid chromatography. J Chromatograph A 977: 89 - 96. https://doi.org/10.1016/s0021-9673(02)01345-6

Song FL, Gan RY, Zhang Y, Xiao Q, Kuang L, Li HB. 2010. Total phenolic contents and antioxidant capacities of selected chinese medicinal plants. Int J Mol Sci 11: 2362 - 2372. https://doi.org/10.3390/ijms11062362

Spiridon I, Bodirlau R, Teaca CA. 2011. Total phenolic content and antioxidant activity of plants used in traditional Romanian herbal medicine. Cent Eur J Biol 6: 388 - 396. https://doi.org/10.2478/s11535-011-0028-6

Valko M, Leibfritz D, Moncol J, Cronin MT, Mazur M, Telser J. 2007. Free radicals and antioxidants in normal physiological functions and human disease, Int J Biochem Cell Biol 39: 44 - 84.

https://doi.org/10.1016/j.biocel.2006.07.001

Vangronsveld J, Clijsters H. 1994. Toxic effects of metals. In: Farago ME ed. Plants and the chemical elementsbiochemistry, uptake, tolerance and toxicity. $\mathrm{VCH}$, Weinheim, Germany.

Verma S, Dubey RS. 2003. Lead toxicity induces lipid peroxidation and alters the activity of antioxidant enzymes in growing rice plants. Plant Sci 164: 645 - 655. https://doi.org/10.1016/s0168-9452(03)00022-0

Whitney E, Rolfe S. 2002. Understanding nutrition. Wadsworth/Thomson Learning Belmont, CA, USA.

Xu DP, Li Y, Meng X, Zhou T, Zhou Y, Zheng J, Zhang JJ, Li HB. 2017. Natural antioxidants in foods and medicinal plants: extraction, assessment and resources. Int J Mol Sci, 18: 96. https://doi.org/10.3390/ijms18010096

Zengin G, Uysal S, Ceylan R, Aktumsek A. 2015. Phenolic constituent, antioxidative and tyrosinase inhibitory activity of Ornithogalum narbonense L. from Turkey: a phytochemical study. Ind Crops Prod 70: 1 - 6. https://doi.org/10.1016/j.indcrop.2015.03.012 